\title{
MATHEMATICAL MODELS FOR HUMAN PILOT MANEUVERS IN AIRCRAFT FLIGHT SIMULATION
}

Authors:

Yan Zhang

EG\&G Technical Services

Cambridge, Massachusetts, USA

Seamus McGovern

U.S. DOT Volpe National Transportation Systems Center

Cambridge, Massachusetts, USA

\begin{abstract}
Mathematical models are presented in this paper to describe human maneuvers for aircraft flight simulation. Input parameters for the human pilot model (HPM), such as the course deviation indicator (CDI) and the heading change, are defined for the model, and are related mathematically to those in the proportional-integral-derivative (PID) controller for automatic control. Similarities are discussed between the parameters in HPM and those in the automatic control for better understanding of the significance of human factors and their effect on aircraft behavior. Examples for the HPM include aircraft instrument landing system (ILS) lateral and vertical control, heading change, and homing. The model is tested by using the high-fidelity flight simulation simulator JSBSim [1].
\end{abstract}

\section{References}

[1] Berndt, J. S., 2008. JSBSim: An Open Source, Platform- Independent, Flight Dynamics Model in C++, v1.0 ed. JSBSim Reference Manual.

[2] X-Plane by Laminar Research. On the WWW. URL http://www.x-plane.com/.

[3] Microsoft Flight Simulator. On the WWW. URL http://www.microsoft.com/games/flightsimulatorXI.

[4] McGovern, S. M., 2007. National Airspace System Stochastic Simulation Aircraft Model Validation Survey. Tech. Rep. DOT-RITA-RTV-4B-07-03-1.0, U. S. DOT Volpe National Transportation Systems Center, Cambridge, MA, May.

[5] McRuer, D., and Jex, H. R. "A review of quasi-linear pilot models". IEEE Trans. on Human Factors in Electronics.

[6] Hosman, R., and Stassen, H., 1999. "Pilot's perception in the control of aircraft motions". Control Engineering Practice, 7(11), November, pp. 1421-1428.

[7] Godwin, P., 2006. Human Factors and Pilot Performance (Air Pilot's Manual S.). Air Pilot Publishing Ltd., London, UK.

[8] Foyle, D. C., 2008. Human Performance Modeling Aviation. CRC Press, New York.

[9] Johnson, E. N., 2002. Generic pilot and flight control model for use in simulation studies. Conference paper, AIAA Modeling and Simulation Technologies Conference and Exhibit, Monterey, CA, 5-8 August.

[10] WGS84, 2000. Department of Defense World Geodetic System 1984. Tech. Rep. NIMA TR8350.2, 3rd edition, National Imagery and Mapping Agency, Cambridge, MA, January. See also URL http://earthinfo.nga.mil/GandG/publications/tr8350.2/wgs84fin.pdf.

[11] Tan, K.-K., Wang, Q.-G., and Hang, C. C., 1999. Advances in PID Control. Springer-Verlag, London, UK. 